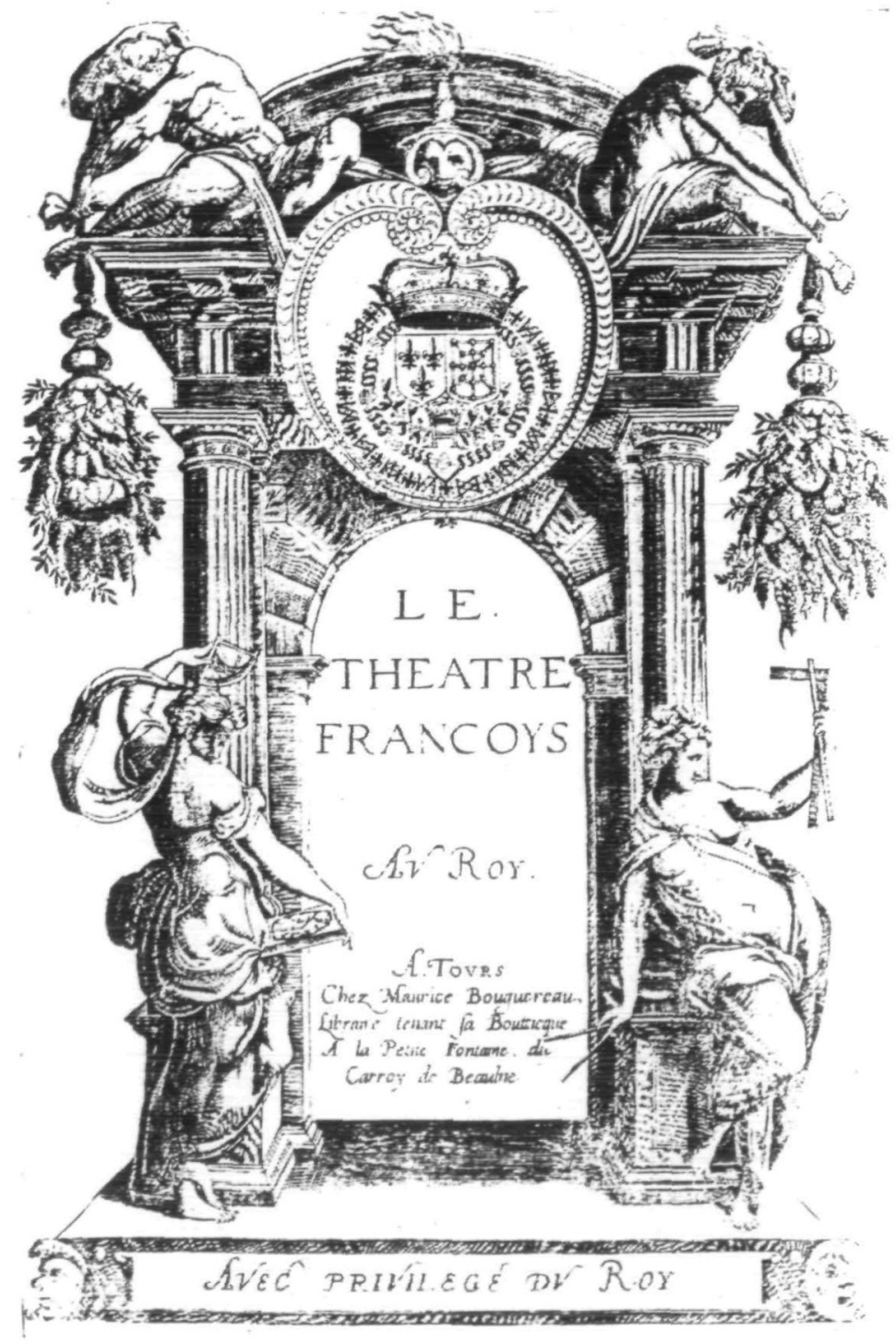

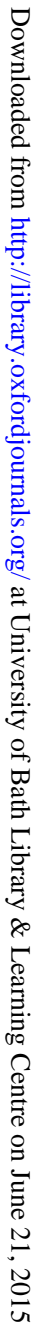

THE ENGRAIED TITLE OF THE THEATRE FRAMCQOIS TOLRS, 1594

FOLIO IN FACSIMILE, REULCED 


\section{NOTE ON A SERIES OF EARLY FRENCH ATLASES, 1594-1637. PRESENTED TO THE BRITISH MUSEUM, $1920^{1}$}

\section{BY SIR H. GEORGE FORDHAM}

7 HE discovery thirty years ago, in the Bibliothèque Nationale, Paris, of a copy of the Theattre François, 1 published at Tours in 1594 by Maurice Bouguereau, 'Imprimeur et Libraire demeurant en la rue de la Seellerie, devant La Trinité,' as he is described on the printed title-page of his atlas, prompted an inquiry into the origin of this work, and a study of the sources from which its maps were drawn, and of the subsequent historical development of the cartography of France and its extension beyond the frontiers of that kingdom in the atlases of Jean le Clerc and his widow (T béatre Géographique du Royaume de France), 1619-1631, and of Jean Boisseau (Theiatre des Gaules), 1642, the whole of which

1 One of two papers read by Sir George Fordham before the Bibliographical Society on 15 November 1920 .

2 See : Drapeyron, Ludovic. Le premier atlas national de France (1589-1594). Bulletin de geograpbis bistorique et descriptice, année 1890 . Paris, 1890, 8vo.

Drapeyron, Ludovic. L'evolution de notre premier atlas national sous Louis XIII. Bulletin de geograpbie bistorique et descriptive, année I 890 . Paris, I890, 8vo.

Bosseboeuf, L'Abbé L. A. La Touraine et les travaux de gégraphis. Tours, 1894,8 ro.

Drapeyron, Ludovic. Notre premier atlas national et la Menippie de Tours sous Henri IV. Paris, 1894, 8vo.

Langlois, Ludovic. L'atlas de Bouguereau. Bulletin trimestriel de la Societé arcbeologique de Touraine, tome XIII. Tours, 1902, 8vo.

Beaumont, Le Comte Charles de. La carte du duche de Touraine en 1592. Bulletin trimestriel de la Sociéte arcbiologique de Touraine, tome XIII. Tours, 1902, 8vo. 
series is founded on the plates of the Tbeatre Franfois of 1594 , with a gradually increasing number of additional maps.

These atlases, with that of Melchior Tavernier, which also bore the title Tbeâtre Géographique du Royaume de France, and was published in Paris in $16_{34}$, constitute the whole of the material of French cartography in atlas form up to the appearance of the collected maps of Nicolas Sanson, of Abbeville (1600-1667), about 1654. From this latter publication is dated the work of the important French school of cartography of which Sanson was the founder.

I have made use of the material of study mentioned in the note at the foot of the preceding page as a basis for a full discussion of the development of interest and activity in the early production of provincial and national maps in France in 2 paper published in the Cambridge Antiquarian Society's Communications, no. lii, vol. xiii (1909), and reprinted, with slight revision, in Studies in Cartobibliograpby, Oxford, 1914, 8 vo, under the title, "The Cartography of the Provinces of France, 1570-1757'.

I may, perhaps, be allowed to point out, in passing, that, in my Catalogue of the County Maps of Hertfordshire ${ }^{1}$ I have very fully examined the parallel activity of the English cartographers, from the appearance of the atlas of Christopher Saxton (1 579), through the publications of John Norden (1 593) and John Speed (I6I1), and the early illustrated editions of Camden's Britannia (1607, 1610, and 1637), and have carried these studies down to the end of the last century.

My own attention was drawn to the subject of the early maps of the Provinces of France published in that country through the rather accidental purchase of a copy of the Thêâtre Franffois in London in 1907. Subsequently I bought,

1 Hertfordsbire Maps: A Descriptive Catalogue of tbe Maps of the County, 1579-1900. Hertford, 1907. 8vo.

Supplement. Hertford, 1914. 8vo. 
in Munich, a second, but less complete copy of this atlas, and, at the same time, secured two examples of different dates, of the Théatre Geographique du Royaume de France of Jean le Clerc and his widow, as well as a copy of Melchior Tavernier's atlas bearing the same title.

These five atlases constitute a series which is not found, as far as I am aware, in the same completeness in any public library, or private collection except my own. Its proper and permanent resting-place seems to me to be the national collection, and it is now to pass by way of gift into the British Museum.

Some short descriptive and historical notes may be worth recording here.

The copies now known to exist of the Theitte Frangois are only six in number : one each in the British Museum and the Bibliothèque Nationale ; one at Tours ; one at Dresden, and the two in my possession. They all differ as to the full-sized general maps of France, of which there are three, copied and reduced from the maps of Guillaume Postel (1570), Petrus Plancius, and Jean Jolivet (1560) respectively. A small, halfpage map of $F$ rance from a plate engraved by Jodocus Hondius in 1591, after Mercator's map of 1585, is found in some copies also.

The remaining maps of various Provinces of France, fifteen in number, were derived from a variety of sources, all of which have been traced except that of the map of Brittany, the last map in the collection.

This atlas is a thin folio volume of eighty-six pages, the maps, with text on the back, making up sixty pages, and the remainder consisting of printed matter, including the titlepages, preface and a number of dedications, addresses, sonnets. acrostics, \&c., some of them on single leaves. In my Cartography of the Provinces of France, 1570-1757, already referred to, an account of this atlas in some detail and 
of the sources from which its maps were derived will be found. 1

The origin of Bouguereau's undertaking is indicated in his own Preface, in which he says: La bonne volonté qu'ay eue d'illustrer ma Patrie, lors que ceste ville de Tours estoit en ce temps de Troubles et Guerres Civiles le reffuge des gens de bien, s'adressa ì moy ung Graveur Flamand, auquel apres avoir faict Graver en Cuyere la Charte de France, je fus lors stimulé, de continuer le Tbeatre Franfois: et audict temps faict graver les autres Cbartes particulieres des Provinces que voyez en ce livre, dont en ay recouvert, partie d'icelles non jamais veués, and in which he asks his readers to supply him with further cartographic materials from which he undertakes to add maps of the other Provinces of France to the series. He did not, however, increase the number of maps, and it was left to Jean le Clerc, nearly a quarter of a century later, to publish a more complete representation in map form of the various Provinces of France.

From the contracts between Bouguereau and his engraver, preserved in the notarial records of Tours, it has been established that the Graveur Flamand referred to by Bouguereau in his Preface was a certain Gabriel Tavernier, a member, no doubt, of the Tavernier family which originated in Antwerp and to which belonged the Melchior Tavernier already mentioned as a cartographer and publisher in Paris.

The date of the first issue of the Theâtre Geograpbique $d u$ Royaume de France of Jean le Clerc, who published in Paris, in the Rue Fremental, at the sign of the Estoile d'Or from at least as early as 1585 , and who in 1617 was established in the $R u e$ Saint Fean de Latran, at the sign of the Sallemandre Royalle, is not known. There is some reason to suppose that this atlas first appeared in 1617 , but the earliest mention of any copy is

1 Studies in Cartobibliography. Oxford, at the Clarendon Press, 1914, 8vo, at p. 128 et seq. 
that found in the Catalogue des Livres de la Bibliotbique de $M$. Secousse, published on the occasion of the sale of this library in 1755 (Paris, 1755, 8vo). In this list the Theatre Géographique de la France, contenant les Cartes des Provinces, par le Clerc, Par. I619, in-fol, occurs.

In the next year an edition is known, and another was issued by Le Clerc in 1621 ; then in 1622 the publication is continued by his widow, with later issues of 1626 and 1631 , and the final form of the atlas occurs as the Théâtre des Gaules, published by Jean Boisseau in 1642. The distribution of the nine copies known to $m e$ is as follows: 1620, Bibliothèque Nationale, Paris ; 1621, University Library, Cambridge ; Odsey ; 1622, Bibliothèque Nationale, Paris ; 1626 , Bibliothèque Nationale, Paris; Odsey; I63 I, Bibliothèque Nationale ; Musée, Angers ; $16+2$, Bibliotheque Nationale, Paris. It will be noticed that the British Museum possesses no copy of this atlas. Those that I am presenting are in a fine state of preservation, with title pages and printed lists of the contents. The number of maps in Le Clerc's collection, as printed in 1620, is 39 , and it had grown to 75 in Boisseau's final edition of 1642 .

My copies contain, in the edition of 1621,43 maps, as enumerated in the printed list, but made up by additions to a total of 82 , the whole set out in a contemporaneous manuscript table, and in that of 1626,48 titles, including 47 plates and 49 individual maps. Both copies include good examples of a map much sought after by collectors in France, namely that entitled L'Isle de France et lieux circonvoysins, on which is represented pictorially the battle of Ivry (I590) and the French and Spanish armies under Henry IV, the Duke of Mayenne and Alexander of Parma, in their various movements round Paris during the great struggle between the King and the League for the possession of the capital.

Lastly I would draw attention to the copy of Melchior Tavernier's Thêatre Geographique du Royaume de France of 
I637, complete, or nearly so, as to its contents and especially as to the title-page and list of maps, the latter being of great rarity. The title differs slightly from the text of the British Museum copy of 1634 , and it appears, from a comparison of these titles, that Tavernier had moved between 1634 and 1637 from the sign of the Rose rouge to that of the Spbere Royalle, both, however, sur le Quay qui regarde la Megisserie. This atlas, which appears to have been bound in Italy, was in rather a fragile condition in regard to many of the maps when it came into my hands, but these have been repaired throughout by an expert Cambridge map-mounter, and they are now fit to be handled without destructive effects. The collection contains a certain number of original maps by Tavernier himself, but is otherwise largely made up of maps of the Dutch and Flemish school.

I am adding a Table des Cartes contenues en ce Livre, containing sixty titles, together with eleven maps, being the fragments of an issue of Tavernier's Thêtre, discovered at Auxerre in 1907, the maps bearing dates from 1627 to as late as 1646. Melchior Tavernier the elder died in 1641 , so that the atlas to which these maps belonged must have been published not earlier than five years after his death.

I may notice that the Bibliotheque Nationale does not, apparently, possess anything better of Tavernier's work than a very miscellaneous volume without title containing $\mathrm{IO}_{4}$ maps, many of them attributable to this cartographic publisher. I do not know of any other issues of this atlas than the three referred to above (1634, 1637, and circa 1646).

This little series, now to be safely housed in the national collection, is in itself sufficiently representative and even exhaustive of the art of the period as applied to national cartography in France, prior, as I have already noticed, to the advent of Nicolas Sanson, and the foundation of his school of French cartography, further developed, after his death, by his 
sons, and their collaborators and successors the Jaillot family, and finally by the Roberts, to whom the materials gradually amassed descended in the early part of the eighteenth century. I hope it may be found that, with the additions now made, the British Museum will contain the best and most complete collection of the early French atlases in the world.

I exhibit here the five atlases and the fragments I have now briefly noticed, and to carry the matter a little further for the present purpose, have added a copy, from my collection, of Sanson's atlas of 1658 (Cartes Generales de toutes les Parties du Monde, ou les Empires, Monarchies, Republiques, Estats, Peuples, Etc. de IAsie, de l'Africque, de IEurope, et de l'Americque, tant Anciens que Nouveaux, sont exactement remarqués, et distingues suivant leur estenduë), and one of the first volume of the great atlas published by the Jaillots, and, as in this case, reissued by Pierre Mortier, at Amsterdam ${ }^{1}$ (Atlas Nouveau, 2 vols., 1696). The latter is, as regards preservation and colouring, the finest copy I have seen.

In taking over the atlases for submission to the Trustees at their next meeting, Mr. de Villiers, the Assistant Keeper in charge of maps at the British Museum, expressed his delight at the prospect of such an acquisition. Sir George Fordham had made the subject of French cartography completely his own, had devoted years of study to it and much patience to the discovery and acquisition of the maps themselves. It was a subject well worthy of research. French cartographers were second only to those of the Netherlands in number and

1 See Fordham, Sir H. G., Liste alpbabitique des Plans et Vues de Villes, Citadelles et Forkeresses qui se trowemt dans le Grand Atlas de Mortier, edition d'Amsterdam de 16.96. Bulletin de géograpbis historique et descriptive, année 1610. Paris, I9I I, 8vo. 


\section{Series of Early French Allases, 1594-1637}

output; in work they rivalled and often excelled them; in accuracy they were far superior.

According to the speaker the cultivation of the study of geography, and especially of cartography, was a thankless task. Nowhere, until 19I4, was geography so neglected as in this world-wide empire. Hakluyt, Purchas, Churchill, and others were merely recorders of foreign activity. If Holland, France, and Italy produced the finest world-atlases of the sixteenth, seventeenth, and eighteenth centuries it was the atlas made in Germany that had a preponderance in the sales of the nineteenth and twentieth. It was now our duty to encourage a more intimate acquaintance with the geography of all those countries we hold by the right of discovery, exploration, and conquest, and men like Sir George Fordham, who fostered the love of cartography, the twin sister of geography, deserved to be regarded as public benefactors.

A facsimile of the signature of Maurice Bouguereau, who is known as having published at Tours during the period 1588-1 596, is given in Les Origines de DImprimerie à Tours (1467-1550) by Dr. E. Giraudet. Tours, 1881, 8vo. 